\title{
Risk Assessment with Failure Mode and Effects Analysis and Grey Relational Analysis Method in Plastic Injection Process
}

\author{
Ceren Ünlükal $^{1^{*}}$, Mine Şenel ${ }^{1}$, Bilgin Şenel ${ }^{1}$ \\ ${ }^{1}$ Munzur University, Department of Industrial Engineering, Tunceli, Turkey
}

\begin{abstract}
This study aims to evaluate the risks that may arise during the production process in a plastic injection manufacturing enterprise with traditional Failure Mode and Effect Analysis (FMEA) and Grey Relational Analysis (GRA). Although it is a widely used analytical technique that helps to identify and reduce the risks of failure in a process, the Failure Mode and Effects Analysis (FMEA) has some drawbacks that the different risks can have the same risk priority values and the weight of risk factors is not take into consideration. This situation has been tried to be eliminated by integrating the FMEA with the GRA. As a result, it is seen that the order of risk priority values of the identified failure changes according to both methods.
\end{abstract}

\section{Introduction}

All businesses in the service or manufacturing sector face risks and hazards from internal and external factors. Businesses that want to take part and be permanent at the markets where the hard competition have to manage their risks well. Risks must be identified and analyzed in order to be managed.

In businesses producing high volume and fast, a process that starts with a failure can result in very large losses if precaution is not taken in time. Failures that occur during production are difficult and high cost to compensate after they reach the customer [1]. For this reason, especially mass production businesses need to keep their risks under control.

The failure rates that occur in the production step in the mass production businesses like plastic injection are very high and this situation leads up both economic inefficiency and loss of confidence in customers for businesses. This study aims that in order to reduce the damages to the business by eliminating the failures that occur in a plastic injection production business, in addition to the Failure Mode and Effects Analysis technique, the Grey Relational Analysis technique has been also applied and the risk priorities have been compared according to two techniques and the effects of the methods on the results have been investigated.

\footnotetext{
* Corresponding author: senelbilgin@gmail.com
} 
This study is arranged as follows: In Section 2, Failure Mode and Effects Analysis is introduced and its drawbacks are given shortly. Grey Relational Analysis and its steps are given in Section 3. Section 4 is about application of risk assessment for plastic injection process. Conclusions are made in Section 5.

\section{Failure Mode and Effects Analysis}

The purpose of the Failure Mode and Effects Analysis (FMEA), which was first introduced into the literature by the application of the American Army and NASA, is to detect and correct the potential problems in the design and production processes $[2,3]$. FMEA is one of the most established methods used in engineering discipline for risk analysis and preventing failure [4]. In this method, which is frequently used to by businesses seeking to maintain the continuity of high quality products and services, it is very important that the root causes of the risks are identified, and their effects reduced $[5,6]$. Early response and prevention of possible failures contribute to reducing system losses.

FMEA, which helps to prioritize risks and failures, consists of three factors: Occurrence (O), Detectability (D) and Severity (S). Risk Priority Numbers (RPN) are calculated by multiplying the numerical values of the risk factors according to the expressions given in Table 1 .

$$
\mathrm{RPN}=\mathrm{O} \times \mathrm{D} \times \mathrm{S}
$$

Table 1. Scales used in traditional FMEA [3]

\begin{tabular}{|l|c|c|}
\hline \multicolumn{2}{|c|}{ (a) Chance of occurrence } \\
\hline Criteria & Score & Possible failure occurrence rates \\
\hline \multirow{2}{*}{ Remote chance of failure } & 1 & 0 \\
& 2 & $1 / 20000$ \\
\hline \multirow{2}{*}{ Low failure rate } & 3 & $1 / 10000$ \\
& 4 & $1 / 2000$ \\
\hline \multirow{2}{*}{ Moderate failure rate } & 5 & $1 / 1000$ \\
& 6 & $1 / 200$ \\
\hline \multirow{2}{*}{ High failure rate } & 7 & $1 / 100$ \\
& 8 & $1 / 20$ \\
\hline \multirow{2}{*}{ Very high failure rate } & 9 & $1 / 10$ \\
& 10 & $1 / 2$ \\
\hline & (b) Chance of non-detection \\
\hline Chance of not detecting fault & Score & Probability of a defect reaching the customer \\
\hline \multirow{2}{*}{ Remote } & 1 & $0-5$ \\
& 2 & $6-15$ \\
\hline \multirow{2}{*}{ Low } & 3 & $16-25$ \\
& 4 & $26-35$ \\
\hline \multirow{2}{*}{ Moderate } & 5 & $36-45$ \\
& 6 & $46-55$ \\
\hline \multirow{2}{*}{ High } & 7 & $56-65$ \\
& 8 & $66-75$ \\
\hline \multirow{2}{*}{ Very high } & 9 & $76-85$ \\
& 10 & $86-100$ \\
\hline Severity & \multicolumn{3}{|c|}{ (c) Severity } & Score \\
\hline Customer will probably not notice & \multicolumn{3}{|c|}{} \\
\hline
\end{tabular}




\begin{tabular}{|l|c|}
\hline Slight annoyance & 2,3 \\
\hline Customer dissatisfaction & $4,5,6$ \\
\hline High degree of dissatisfaction & 7,8 \\
\hline Safety/regulatory consequences & 9,10 \\
\hline
\end{tabular}

The higher the RPN that can be at any value between 1 and 1000, the more critical it is. The highest RPN value has been highest priority for the potential failure. Corrective action should be planned for each failure by prioritizing the RPN value from highest to lowest. It is not necessary to plan corrective action for failures that are less than 100 RPN value.

Although FMEA has gained huge acceptance and applications in a wide range of industries and helps the analysts prioritize the identified failure modes and work out corrective actions, it has been some limitations and criticized for various reasons [7-13]:

- Some failure modes that have different risk factor values may have the same RPN value, but real risk implications may be completely different. For example, two different failures with the $\mathrm{O}, \mathrm{S}$ and $\mathrm{D}$ values of 2,5,4 and 8,5,1, respectively, have the same RPN value of 40 (Eq.1). However, the risk implication is not same.

- In traditional FMEA, O, S, and D risk factors are considered as equally important. However, for each business, these factors may not have equal importance.

- The mathematical formula for calculating RPN is questionable and debatable. There is no rationale as to why $\mathrm{O}, \mathrm{S}$ and $\mathrm{D}$ should be multiplied to produce the RPN.

- The RPN scale is not continuous with many holes, because many numbers between 1 and 1000 cannot be obtained from the product of $\mathrm{O}, \mathrm{S}$ and $\mathrm{D}$.

- The three factors are difficult to numerically detection. Much information in FMEA can be expressed linguistically such as likely, important or very high and so on.

In this study, the Grey Relational Analysis method will be used and the results will be compared in order to eliminate all these problems and prioritize the failures easier and more accurately.

\section{Grey Relational Analysis}

Grey Relational Analysis (GRA) is one of the subheadings of Grey Theory which was introduced by Julong Deng in 1982. [14,15]. The grey system which is between the white system, where information is completely known, and the black system, where information is not completely known, expresses poor, incomplete and uncertain information $[16,17]$.

GRA which is an interdisciplinary analysis technique investigates the factors affecting the system and determines the dependence of these factors on each other. In addition to determining the interrelationships between multiple factors, it also detects which factor become prominent [18]. It has been successfully applied on cluster analysis, path planning, selection problems, prediction analysis, performance evaluation, factor effect evaluation, decision making and also FMEA [19-21].

In the FMEA method, GRA is applied according to the following steps [3]:

Step 1. Establish comparative series: The information series consisting of O, D and S can be expressed as follows.

$$
x_{i}^{\prime}=\left(x_{i}^{\prime}(1), x_{i}^{\prime}(2), \ldots, x_{i}^{\prime}(k)\right) \in X, i=1,2, \ldots, n
$$


$\mathrm{k}$ is number of the risk factors and $\mathrm{n}$ is number of the failure modes. $x_{i}(k)$ denotes the $\mathrm{k}^{\text {th }}$ factors of $x_{i}$ and the $\mathrm{n}$ information series can be described as the following matrix [3]:

$$
x=\left[\begin{array}{l}
x_{1} \\
x_{2} \\
\cdot \\
\cdot \\
x_{n}
\end{array}\right]=\left[\begin{array}{llll}
x_{1}(1) & x_{1}(2) & \ldots & x_{1}(k) \\
x_{2}(1) & x_{2}(2) & \ldots & x_{2}(k) \\
\cdot & & & \\
\cdot & & & \\
x_{n}(1) & x_{n}(2) & \ldots & x_{n}(k)
\end{array}\right]
$$

Equation 2 is a matrix that express $\mathrm{O}, \mathrm{D}$ and $\mathrm{S}$ values for each failure mode.

Step 2. Establish the standard series: The purpose of defining standard series is to determine the degree of relation [22]. Standard series is established according to the lowest score of the risk factor scale.

$$
x_{0}=\left(x_{0}(1), x_{0}(2), \ldots, x_{0}(k)\right)=(1,1, \ldots, 1)
$$

Step 3. Obtain the difference between the comparative series and standard series: To obtain the difference matrix, the difference between the comparative series and standard series must to be calculated.

$$
\Delta_{0 i}(k)=\left[\begin{array}{llll}
\Delta_{01}(1) & \Delta_{01}(2) & \ldots & \Delta_{01}(k) \\
\Delta_{01}(1) & \Delta_{01}(2) & \ldots & \Delta_{01}(k) \\
\cdot & & & \\
\cdot \\
\Delta_{0 n}(1) & \Delta_{0 n}(2) & \ldots & \Delta_{0 n}(k)
\end{array}\right] \text { and where } \Delta_{0 i}(k)=\left|x_{0}(k)-x_{i}(k)\right|
$$

Step 4. Compute the grey relational coefficient: To calculate grey relational coefficient, we use the following equation:

$$
\gamma\left(x_{0}(k), x_{i}(k)\right)=\frac{\Delta_{\min }+\zeta \Delta_{\max }}{\Delta_{0 i}(k)+\zeta \Delta_{\max }}
$$

$\zeta \in(0,1)$ is an identifier coefficient and only affects the relative value of the risk without changing the priority [22].

Step 5. Determine the degree of relation: There are two approaches to determine the degree of relation. Firstly, we assume that all of risk factors have equal importance;

$$
\tau_{i}(k)=\frac{1}{n} \sum_{k=1}^{n} \Delta_{i}(k)
$$

If the risk factors do not have equal importance;

$$
\tau_{i}(k)=\sum_{k=1}^{n} \Delta_{i}(k) \beta(k) \text { and } \sum_{k=1}^{n} \beta(k)=1
$$

$\beta(k)$ is the weights of the risk factors and determined by the experts work in plastic injection business.

Step 6. Obtain the relational series to rank the priority of risk: The lower degree of relation represents the higher risk priority. As the degree of relation is closer to 1 , it means the failure mode is closer to the optimal value [22]. 


\section{Application}

This study aims to reduce the risks by determining the failures that can occur during the period from production to delivery in a company that produces plastic injection for the white goods, bathroom accessories and complementary wares sector in Eskisehir. The risk analysis studies are first performed with traditional FMEA and then Grey Relational Analysis is applied to determine the risk priorities according to these methods.

A team consisting of a quality control manager, a quality control engineer and a production manager is made. The experts are identified problems that could arise during and after the production process. Table 2 lists failures occurring in the firm.

Table 2. Failure modes and definitions

\begin{tabular}{|c|c|c|}
\hline $\begin{array}{l}\text { Failure } \\
\text { Mode }\end{array}$ & Failure & Failure Definition \\
\hline FM1 & Warpage & $\begin{array}{l}\text { Warpage can be defined as a dimensional distortion in a molded product } \\
\text { after it is ejected from the mold at the end of the injection molding } \\
\text { process [23]. }\end{array}$ \\
\hline FM2 & Flash/Burrs & $\begin{array}{l}\text { Flash is a molding defect that occurs when some molten plastic escapes } \\
\text { from the mold cavity [24]. }\end{array}$ \\
\hline FM3 & Short shot/Non-fill & $\begin{array}{l}\text { Short shot can be defined as an incomplete molded part caused by } \\
\text { insufficient material injected into the mold [23]. }\end{array}$ \\
\hline FM4 & Label defect & Incorrect filling of card containing information about product \\
\hline FM5 & $\begin{array}{l}\text { Assembly/Grouping } \\
\text { defects }\end{array}$ & $\begin{array}{l}\text { Incorrect grouping of multiple parts or incorrect selection of parts to be } \\
\text { grouped (Manual assembly) }\end{array}$ \\
\hline FM6 & Brittleness & $\begin{array}{l}\text { Brittleness can be defined as the tendency of a molded plastic part to } \\
\text { break or crack under conditions in which it would not normally do so } \\
{[23] \text {. }}\end{array}$ \\
\hline FM7 & Dimensional defects & Incorrect product size (out of tolerance values) \\
\hline FM8 & $\begin{array}{l}\text { Cracked/Broken } \\
\text { product }\end{array}$ & Some parts of the product are cracked or broken. \\
\hline FM9 & $\begin{array}{l}\text { Oily, dirty and } \\
\text { stained product }\end{array}$ & $\begin{array}{l}\text { It means that oiling and contamination of product after remove from the } \\
\text { mold. }\end{array}$ \\
\hline FM10 & Discoloration & $\begin{array}{l}\text { Discoloration can be defined as a change in the original } \\
\text { color of a plastic material [23]. }\end{array}$ \\
\hline FM11 & Burn marks & $\begin{array}{l}\text { Burn marks can be defined as small dark brown or black discolorations } \\
\text { on the surface of a molded part [23]. }\end{array}$ \\
\hline FM12 & $\begin{array}{l}\text { Shipment of wrong } \\
\text { product }\end{array}$ & Sending wrong product that is not suitable for customer order \\
\hline FM13 & Afterflame & $\begin{array}{l}\text { Afterflame is the duration of the material burning after the combustion } \\
\text { source is removed. }\end{array}$ \\
\hline FM14 & Surface defects & $\begin{array}{l}\text { Surface defects express the scratches, gouges, specks and blisters on the } \\
\text { product surface. }\end{array}$ \\
\hline
\end{tabular}

$\mathrm{O}, \mathrm{D}$ and $\mathrm{S}$ risk factors for each failure modes listed in Table 2 are evaluated by experts and arithmetic mean values are calculated. According to Equation 1, O, D and S mean values are multiplied and obtained RPN. Similar calculations are made with GRA, too. There are two different approaches in GRA. The first is that the risk factors have been equal importance. The other is that the weights of risk factors are determined by experts. The weights determined with Pair-Wise Comparison method are given in Table 3. And then the risk priorities are determined and ordered according to the RPN values. 
Table 3. The weights of risk factors

\begin{tabular}{|l|c|}
\hline Risk Factors & Weights \\
\hline Occurrence & 0,23 \\
\hline Detectability & 0,15 \\
\hline Severity & 0,62 \\
\hline \multicolumn{2}{|l|}{ Consistency Rate: 0,01} \\
\hline
\end{tabular}

The results are shown in Table 4 and the RPN values are listed according to the GRAFMEA method, which is obtained both by traditional FMEA and by the approach of equal and different weights.

Table 4. Comparison of priorities determined by different methods

\begin{tabular}{|c|c|c|c|c|c|c|}
\hline $\begin{array}{c}\text { Failure } \\
\text { mode }\end{array}$ & $\begin{array}{c}\text { Traditional } \\
\text { RPN }\end{array}$ & Rank & $\begin{array}{c}\text { Grey RPN } \\
\text { (Equal weight) }\end{array}$ & Rank & $\begin{array}{c}\text { Grey RPN } \\
\text { (Unequal weight) }\end{array}$ & Rank \\
\hline FM1 & 114 & 9 & 0,64 & 9 & 0,64 & 7 \\
\hline FM2 & 199 & 5 & 0,58 & 4 & 0,61 & 6 \\
\hline FM3 & 222 & 3 & 0,56 & 3 & 0,58 & 5 \\
\hline FM4 & 30 & 14 & 0,82 & 14 & 0,83 & 14 \\
\hline FM5 & 346 & 2 & 0,51 & 2 & 0,54 & 3 \\
\hline FM6 & 164 & 6 & 0,61 & 6 & 0,56 & 4 \\
\hline FM7 & 487 & 1 & 0,47 & 1 & 0,48 & 1 \\
\hline FM8 & 51 & 12 & 0,75 & 11 & 0,69 & 10 \\
\hline FM9 & 62 & 10 & 0,73 & 10 & 0,75 & 11 \\
\hline FM10 & 148 & 7 & 0,62 & 8 & 0,65 & 8 \\
\hline FM11 & 36 & 13 & 0,80 & 13 & 0,76 & 12 \\
\hline FM12 & 144 & 8 & 0,62 & 7 & 0,66 & 9 \\
\hline FM13 & 203 & 4 & 0,59 & 5 & 0,53 & 2 \\
\hline FM14 & 61 & 11 & 0,75 & 12 & 0,77 & 13 \\
\hline
\end{tabular}

It is seen that the highest risk is FM7 (Dimensional defects) and the lowest risk is FM4 (Label defect) according to all of methods. It means corrective actions should be planned for FM7 firstly. And then for each failure mode exceeding 100 RPN value, corrective action should be planned.

The main reason for changing the rest of the ranks is that the importance level of the risk factors changes according to experts' opinions. Because importance level of $\mathrm{O}, \mathrm{D}$ and $\mathrm{S}$ risk factors changes according to business sector and it differs according to firms and experts.

\section{Conclusion}

Traditional FMEA is practical and helpful for risk assessment, but it may not be sufficient when used alone. In this study, FMEA and GRA methods are used together to 
assess and prioritize the risks more effectively and realistic. Weights of risk factors determined according to experts' opinions are also included in the calculation and all the results are compared. It has been observed that the order of priority differs according to all the methods. It has been determined that the FMEA based GRA method which takes the firm priorities into account is useful. This study will be helpful for other plastic injection firms to assess their risks. Fuzzy logic and multi-criteria decision-making methods can be used in future work and the results can be compared with FMEA based GRA method.

\section{Acknowledgements}

Authors would like to thank to Şefik Tanrısevdi, who works as the quality control manager at the firm, for his great contributions.

\section{References}

1. M. Zerenler, K. Karaboğa, "Müşteri Memnuniyetinin Sağlanmasında Hataların Önlenmesine Yönelik Üretim Odaklı Bir Bakış Açısı: Poka-Yoke Sistemleri”, Selcuk University Journal of Institute of Social Sciences, Dr. Mehmet YILDIZ Special Edition, 263-275, 2014.

2. P. M. Özfirat, "Bulanık Önceliklendirme Metodu ve Hata Türü ve Etkileri Analizini Birleştiren Yeni Bir Risk Analizi Yöntemi”, Journal of the Faculty of Engineering and Architecture of Gazi University, Vol 29, No 4, 755-768, 2014.

3. C. L. Chang, C. C. Wei, Y. H. Lee, "Failure Mode and Effects Analysis Using Fuzzy Method and Grey Theory", Kybernetes, Vol. 28 Issue: 9, pp.1072-1080, 1999.

4. R. E. McDermott, R. J. Mikulak, M. R. Beauregard, "The Basics of FMEA", Productivity Press 2nd edition, ISBN 9781563273773, 2008.

5. W. C. Ng, S. Y. Teh, H. C. Low, P. C. Teoh, "The Integration of FMEA with Other Problem Solving Tools: A Review of Enhancement Opportunities", Journal of Physics: Conference Series 890/012139, 2017.

6. C. Kahraman, İ. Kaya, Ö. Şenvar, "Healthcare Failure Mode and Effects Analysis Under Fuzziness", Human and Ecological Risk Assessment, 19:2, 538-552, 2013.

7. K. S. Chin, Y. M. Wang, G. K. K. Poon, J. B. Yang, "Failure Mode and Effects Analysis Using A Group-Based Evidential Reasoning Approach", Computers \& Operations Research, 36, 1768-1779, 2009.

8. J. B. Bowles, “An Assessment of PRN Prioritization in A Failure Modes Effects and Criticality Analysis", Journal of the IEST, 6, 47-51, 2004.

9. N. R. Sankar, B. S. Prabhu, "Modified Approach for Prioritization of Failures in A System Failure Mode and Effects Analysis", International Journal of Quality \& Reliability Management, 18(3):324-35, 2001.

10. M. Ben-Daya, A. Raouf, "A Revised Failure Mode and Effects Analysis Model", International Journal of Quality \& Reliability Management, 13(1):43-7, 1996.

11. M. Braglia, M. Frosolini, R. Montanari, "Fuzzy Criticality Assessment Model for Failure Modes and Effects Analysis", International Journal of Quality \& Reliability Management, 20(4):503-24, 2003.

12. W. Gilchrist, "Modelling Failure Modes and Effects Analysis", International Journal of Quality \& Reliability Management, 10(5):16-23, 1993. 
13. A. Pillay, J. Wang, "Modified Failure Mode and Effects Analysis Using Approximate Reasoning", Reliability Engineering \& System Safety, 79:69-85, 2003.

14. N. Uçkun, N. Girginer, “Türkiye'deki Kamu ve Özel Bankaların Performanslarının Gri İlişki Analizi ile İncelenmesi”, Akdeniz University Faculty of Economics \& Administrative Sciences Faculty Journal, 21: 46-66, 2011.

15. D. Julong, "Control Problems of Grey Systems, Systems and Control Letters", 5,28894, 1982.

16. N. Tosun, "Determination of Optimum Parameters for Multi-Performance Characteristics in Drilling by Using Grey Relational Analysis", The International Journal of Advanced Manufacturing Technology, 28, 450-455, 2006.

17. D. Julong, "Introduction to Grey System Theory", The Journal of Grey System, 1, 1 24, 1989.

18. C. Erden, E. Ceviz, "Gri Sistem Teorisi Kullanılarak Türkiye’nin Büyüme Oranı Faktörlerinin Analizi”, Sakarya University Journal of Science, 19:3, 361-369, 2015.

19. K.C. Chang and M.-F. Yeh, "Grey-Relational Analysis Based Approach for Data Clustering”, IEEE Proceedings - Vision Image and Signal Processing, 152(2):165-172, 2005.

20. H. C. Lu, M. F. Yeh, "Robot Path Planning Based on Modified Grey Analysis", Cybern. Syst., 33(2):129-159, 2002.

21. M.-F. Yeh, H. C. Lu, "Evaluating Weapon Systems Based on Grey Relational Analysis and Fuzzy Arithmetic Operations”, J. Chinese Inst. Eng., 23(2):211-221, 2000.

22. Ç. Sofyalıoglu, Ş. Öztürk, "Application of Grey Relational Analysis with Fuzzy AHP to FMEA Method”, Doğuş University Journal, 13(1):114-130, 2012.

23. http://www.plastictroubleshooter.com/ThePlasticTroubleshooter/defects.htm (23.05.2018)

24. https://www.creativemechanisms.com/blog/what-cause-injection-molding-defects-andhow-to-fix-them (23.05.2018) 